\title{
Anthroponyms and Phytonyms in Latvian Literary Fairy Tales and Their Translation in Lithuanian (Flowers: Fairy Tales by Anna Sakse)
}

\section{Abstract}

Lithuanian readers can enjoy the translations of fairy tales by the Latvian authors Kärlis Skalbe, Anna Sakse, Margarita Stāraste, Imants Ziedonis and Juris Zvirgzdiñ̌̌. Literary fairy tales and their translations make interesting material for study; also, it is intriguing to consider how texts written for Latvian children are perceived by Lithuanian children.

The aim of this study is to find out what language conformities and peculiarities have been taken into consideration in the process of translating Latvian literary fairy tales into Lithuanian. Attention is focused on one of the proper name groups anthroponyms, as well as appellatives related to them - phytonyms.

The study material includes the cycle of fairy tales "Flowers: Fairy Tales" by Anna Sakse and their translation into Lithuanian (translator Renata Zajančkauskaite). The study has been carried out by contrastive analytical, descriptive and interpretation methods. Mainly fairy tales with certain discrepancies between the anthroponyms and phytonyms in the source and target languages were selected for the present analysis.

The analysis allows to conclude that the anthroponyms and phytonyms used by the author reflect the cultural environment of various countries of the world. Anna Sakse links anthroponyms with phytonyms either directly (the words can be either actual people's names or personified appellatives) or in a more or less indirect manner. In the translated fairy-tale texts the reader can find the same anthroponyms and/ or phytonyms as in the source text, however, one can identify also cases of cultural substitution. Sometimes the choice of a different personal name can be justified by the fact that the gender of the word differs in Latvian and Lithuanian, and therefore a literal transfer is not possible. The cycle contains fairy tales that have been translated into Lithuanian not because their phytonyms match but because of the development of the plot or associations implied.

Key words: anthroponym, phytonym, literary fairy tale, Latvian literature, Lithuanian translation

\section{Introduction}

There is a number of publications, including fairy tales, addressed to various age groups (children and young people being among them) that are translated and published in Lithuanian (see Gaižūns, 2008; Kvašìte, 2008, to find out more about the translations of Latvian literary works into Lithuanian). For instance, since 1990 
five folk and seven literary fairy tale books have been translated from Latvian and/ or repeatedly published. Some of them have been written by well-known Latvian fairy tale authors such as Kārlis Skalbe (Pasakas - Lith. Pasakos. 2007, containing 57 fairy tales), Anna Sakse (Kalējdēls Kaspars - Lith. Milžino šauksmas. 1993; Pasakas par ziediem - Lith. Pasakos apie gèles. 2005), Margarita Stāraste (Zili brīnumi zaḷā dārzā - Lith. Stebuklai žaliam darže. 1998), Imants Ziedonis (Krāsainās pasakas - Lith. Spalvotos pasakos. 2006); some tales belong to the pen of not so popular writers, for instance, Juris Zvirgzdinšš (Tobiasa blēn,u stāsti - Lith. Tobijo paistalai. 2006). Literary fairy tales and their translations make a stimulating material for study; also, it is interesting to examine how Lithuanian children perceive texts that originally have been written for Latvian children.

\section{Aim of the study, materials and methods}

The aim of this study is to find out language conformities and peculiarities in the Lithuanian translation of the fairy tale cycle by Anna Sakse Flowers: Fairy Tales (Pasakos apiegeles). Since it is impossible to cover all characteristics of the translation in one article, the author shall focus on one of the proper name groups - personal names (anthroponyms), and appellatives - plant names that are related to them (phytonyms ${ }^{1}$. Each fairy tale in the cycle is dedicated to one or several personified flowers, therefore it is of great interest to analyse the personal names given to the fairy tale characters to see and compare how the translator has reconstructed them in Lithuanian².

This study is based on literary onomastics, i. e., the theory and practice of using anthroponyms, toponyms and other proper names in fiction. Literary anthroponyms have a specific function: they characterise story characters, relationships between them, they give a locally temporal characterisation, etc. (Bormane, 2006, 14). However, so far relatively few studies have been carried out on the translation of anthroponyms. The theoretic statement that anthroponyms (as well as other proper names) need not be translated in fiction but only adapted to the grammatical system of the target language is too simplified and not always applicable or even grounded. "Reproduction of anthroponyms in a literary text cannot be examined separately from the introduction of the word in the original; that is why both the translator's strategy and the hierarchy of equivalents in reproducing literary proper names are closely linked with the author's intentions. The translator's tasks (for instance, when translating fairy tales, children's books, different literary texts) include also developing the ability to sense connotations related to proper names" (Bormane, 2006, 16). Grammatical transfer of a word that has been purposefully chosen or coined by the author and has a symbolic meaning, accentuating some

In Latvian, a phytonym is a proper name that denotes a particular plant (usually, a tree) (VPSV 2007, 114), however, this term is also used to refer to appellatives - plant names - in other sources (Gritènienè, 2006).

A Bachelor Paper on the above-mentioned theme was presented in the University of Šiauliai (Valutytè, 2007). 
peculiar traits of a character or other features etc. would only result in a loss of the meaning. Theoretic studies and translation practice lead towards several methods for reproducing proper names. After analysing Latvian translations of Alexander Pushkin's works, Bormane describes and uses several reproduction types offered by Jermoloviča: 1) direct transfer of the initial form of the word into the translation; 2) choice of an onomastic equivalent (transcription, transliteration or a traditional equivalent); 3) translation with a comment; 4) specified translation (an onomastic equivalent is specified with the help of one or several explanatory words in the very text); 5) descriptive translation (the meaning of the proper name is reproduced with the help of a common noun or a phrase); 6) transforming translation (another proper name is used) (Bormane, 2006, 14-15). This method can be partially compared to cultural substitution, i. e., a method "that is used in the translation process in order to describe an unknown object, a phenomenon or a process mentioned in the source text: the translator uses a functionally similar name of the realities, descriptions etc. existing in the target language..." (VPSV, 2007, 198). The above method becomes especially important when the story is telling about a foreign cultural environment or when unknown reality and names connected with it come into play, these being hard to reproduce in another language. Several of the methods mentioned have been used in the Lithuanian translation of the fairy tales by Anna Sakse.

To carry out the present study contrastive analytical, descriptive and interpretation methods were used.

\section{Results}

Material of the study: Flowers: Fairy tales by Anna Sakse. The cycle Flowers: Fairy Tales comprises 33 fairy tales (1966): Sniegpulkstenite (Snieguolè) ${ }^{3}$, Forsteriāna (Forsteriana), Pienenīte (Pienè), Kirsis (Vyšnia), Cūkausītis (Kiaulausiukas), Narcise (Narcizas), Hiacinte (Hiacintas), Zaka kāposti (Zuikio kopūstai), Jasmīns (Jazminas), Persijas cerinš (Persijos alyva), Vijolïte (Kvaputè), Magone (Aguona), Lapsaste (Lapiu uodegos), Kurpītes (Kurpelès), Kamēlija (Kamelija), Saulgrieze (Saulègrąža), Lotoss (Lotosas), Naktsvijole (Raganiukè), Czi-Czina (Czi Czina), Mežaroze un Rìtavējš (Erškètrože ir Ryto Vejjas), Lauztā sirds (Širdelès), Gladiola (Gladiolés), Puku zirnītis (Žirniukas), Titenis (Vijoklis), Sausziedis (Sausažiedis), Dzegužasara (Gegutès ašaros), Üdensroze (Vandens lelija), Lilija (Lelija), Orhideja (Orchideja), Balzamine (Balzamina), Granātkoks (Granatmedis), Peonija (Pinavija), Magnolija (Magnolija). "Noticing many similarities between natural and social phenomena (Titenis, Sausziedis) as well as characteristics of flowers, birds and trees that appear also in the nature of a human being (Dzegužasara, Vijolite) Anna Sakse draws the two worlds closer. The border between them has been left open, and the relationships between the real and fantastic get diffused (Pienenite), thus giving birth to associations and subtexts,

The name of the respective fairy tale from the Lithuanian edition is given in brackets (2005). 
and literally implementing the idiom "flowery speech" (Daneberga, 1990, 107). Each of the tales has an original interpretation of the origin of various flowers or other blooming plants (bushes, trees) and their names. "Outer resemblance relates flower fairy tales by Anna Sakse with aetiological folk tales and legends explaining the origin of various natural phenomena. Not only in legends, but in the writer's fairy tales, too, do unseen flowers start blossoming in places where heroes have died in a futile attempt to attain their aims they have been striving for" (Daneberga, 1990, 108).

The writer tells us about plants of local origin and foreign or exotic plants. The different cultural environments are revealed through anthroponyms as well as plants symbolising realities of a particular nation and its environment. "One can come across stories and motives from both Latvian and foreign folklore (for instance: Naktsvijole, Puku zirnītis, Persijas cerinš, Kurpītes, Hiacinte and Narcise); characters from wonder fairy tales, for instance, dwarfs in the tale Kurpites or a dragon in Persijas cerinš)..." (Daneberga, 1990, 108). The visual image of the book is the first to capture the reader's attention. Both the Latvian and Lithuanian editions analysed have been illustrated with photographs whereas the original edition in Latvian contains illustrations by the famous Latvian painter Kārlis Sūninšs.

The first edition of the fairy tales by Anna Sakse in Lithuanian was published in Lithuania in 1969 under the title Pasakos apie geles; the second edition came out in 2005. It was translated by Renata Zajančkauskaite, an experienced translator, who admits she is a fan of the fairy tale genre (she has also translated fairy tales from French) and considers the author's rich and beautiful language a decisive factor for the selection of a text (Kanopkaite, 2009). The flower tales appear to be a lucky choice.

Part of the fairy tales are easily perceived and understood by children; some of them tell about children, for instance, Cükausītis, Pienenìte, Zak, kāposti, Puku zirnìtis, Kirsis. The rest, on the other hand, are addressed to various age groups, therefore before choosing a fairy tale one should consider both the text and the addressee. In this study the correlation between the plot of the tale and the addressees' age group shall not be considered specifically. The main interest of the researcher lies in the choice of anthroponyms, their relation to phytonyms in Latvian and the ways they are depicted in the Lithuanian translation.

Anthroponyms and phytonyms of foreign origin. When analysing the Latvian text and its translation into Lithuanian, one can see that the greatest challenge is posed by the gender difference between the anthroponym and phytonym (i. e., appellative). The differences can be seen in the fairy tales that have phytonyms of foreign origin: Narcise (PZ, 38-43) ${ }^{4}$ and Hiacinte (PZ, 44-49). The main characters of both fairy tales are boys - Narciss un Hiakints:

PZ stands for Pasakas par ziediem and PG for Pasakos apie geles; the abbreviation is followed by the page number. 
Kad upes dievam Kēfisam un nimfai Leiriopei piedzima dēls Narciss, viñi nevarēja vien nopriecāties par skaisto, veselïgo bērnu. - Manu baltvaidzït, manu spulgacìt, manu sproggalvìt, - tā Leiriope mīlinādamās sauca savu zēnu (PZ, 39).

Kādreiz likās, ka nav tādas varas, kas spètu iedragāt dieva Apolona un valdnieka dèla Hiakinta draudzību (PZ, 45).

The personal name Narciss has originated from the Greek language: "Narkissos [gr.: narkē'sleep, numbness'...] - myth. a young man renowned for his beauty who saw his own reflection in a pool, madly fell in love with it, and wasted away to death; a flower called narcissus grew in that place" (Silinšs, 1990, 246). The name of the second man also comes from the Greek language: "Hiakints (-k : c-) gr. Hyakinthos - a beautiful young man and lover of god Apollo who, as the myth tells, was accidentally killed by Apollo when he was throwing a discus; a sweet-smelling flower grew from his spilt blood" (Silin,š, 1990, 153). The plants that grew after the death of both young men have been used in the feminine forms (obviously, the Latvian nomenclature word for flower puke has influenced this approach). Yet, it should be acknowledged that the name of the flower Narciss is never mentioned in the text (either Latvian or Lithuanian); it is related to the personal name only in a descriptive way:

.. lai nezustu Narcisa piemin, iestādīja vin, bojāejas vietā puḳi, kas uzziedēja balta kā Narcisa vaigs (PZ, 43).

The ending of the other fairy tale contains a phytonym:

Apolons, neieguvis Dafni, arvien vēl juta greizsirdību pret Hiakintu...

svecìtes uzziedēja kā puḳes un liesmu vietā virmoja smaržas, spēcīgas kā neizdzivotas jaunïbas sauciens pēc laimes. Hiacintes (PZ, 49).

In Lithuanian, however, the origin of both Greek anthroponyms and phytonyms correspond: the word Narcizas (PG, 37-43) and the name of the flower narcizas; similarly, Hiacintas (PG,44-49) and hiacintas. That is why there are no difficulties in reproducing them in the translation.

As it can be seen from the fairy tales referred to before, the "geographical homeland" of Anna Sakse's stories varies: it is Uzbekistan for Forsteriāna, India for Lotoss, Japan for Kamélija etc.) (Daneberga, 1990, 108). The characters have been given not only actually existing names of foreign origin but also personified appellatives. For instance, the phytonym lotoss that comes from the Greek word lotos has been used for the above purpose in the fairy tale Lotoss (PZ, 106-111). This is the name given to a water plant that is kindred to water lilies and has large leaves and magnificent blossoms (SV, 1999, 444). The fairy tale tells about a girl who has been given this name, however, there is a grammatical contradiction since in Latvian lotoss is a masculine noun (most probably the choice of the name is connected to the splendour of the blossom and the places where the plant grows). 
Tveicīgà vasaras naktī radžas meita Lotoss izgāja pils dārzā pastaigāties (PZ, 107).

It is hard to understand from the text how the anthroponym has been inflected. Judging from the various forms of inflections used throughout the text, it could be either a masculine noun of (i)o- origin or a feminine noun of $i$ origin. Sometimes it is an undeclinable word - this is the case when it is used in a group of words where the basic component is inflected:

- Es nāku, es steidzos, es tūlìt būšsu pie tevis, - bija princeses Lotoss pēdējie vārdi .. Kopš tā laika Gangā sāka augt puke, kas atgādina princesi Lotosu .. (PZ, 111).

In the text of the Lithuanian translation Lotosas (PG, 104-109) there is neither grammatical nor notional unconformity (in Lithuanian the phytonym lotosas is a masculine noun) since the translator has given the character a phonetically similar name that has no etymological relation: radžos dukte Lota (PG, 104) [the daughter of rajah Lota], gèle, kuri primena princesę Lotą (PG, 109) [a flower resembling princess Lota].

As the female name Lote has originated from the name Šarlote, which, in its turn, comes from the male personal name Šarls, derived from Karls from Ancient High German karl "a decent man", also Frank carel "a man" (Silin,̌̌, 1990, 220; 300; 191), the direct link with the cultural environment described in the fairy tale has been lost. However, it is not the most important aspect in this case. The name of princess Lota (the dictionary of Lithuanian personal names does not enlist this shortened form) sounds alien; there is only a formal closeness between the anthroponym and the phytonym. However, since the name is shorter this kind of substitution allows Lithuanian readers, including children, to perceive the text more easily.

Conformities between phytonyms of local and foreign origin. The motivation of using the phytonym of foreign origin in the fairy tale Gladiola (PZ, $146-151)$ is not rooted in the characters' names but in their occupation. There is a difference between the appellatives in Latvian and Lithuanian. The fairy tale tells about two young men - Teress and Sevts - who became gladiators and were later killed because of rebelling. From the swords that they stuck into the ground there grew flowers:

.. zemē iedurtie zobeni sāka zalotot, tiem parādijjās pumpuri un uzplauka ziedi. Šîs pukes nosauca par gladiolām (PZ, 151).

The name of the flower comes from the Latin word gladiolus "a small sword" (after sword-shaped leaves) - bot. is a genus of perennial bulbous flowering plants in the iris family (around 200 species), calescent plants with large, beautiful blossom spikes (SV, 1999, 250). In the Lithuanian translation the fairy tale has a similar title - Gladioles (PG, 146-151), most probably with an aim to preserve the impression of foreign environment and atmosphere, as well as an occupation characteristic of Roman Empire (comp. gladiatorius).

$<. . .>$ i žemę ibesti kardai sužaliavo, išsprogo pumpurai ir prasiskleidè žiedai.

Tos gèlés buvo pavadintos gladiolemis (PG, 151).

However, Lithuanians use the local word kardelis "a little sword" more often 
than the foreign word gladiole (reference gladiole žr. kardelis exists, for instance, in the dictionary of modern Lithuanian language (DLKŽe), whereas the dictionary of foreign words gives ntk. (neteiktinas) - "undesired" (TŽŽ, 2001, 271). Bilingual dictionaries display a similar picture: gladiola "bot. kardelis, gladiolè (Gladiolus)" (LLŽ, 2003, 213) and kardelis - gladiola (LLV, 1995, 215). According to the Lithuanian phytonym researcher Griteniene, the names of the flower in many dialects are connected with swords (in Lithuanian kardas, kalavijas) due to the plant's long and narrow leaves. The initial source of such motivation was the Latin language (Gritenienè, 2006, 68). Taking into consideration the fact that flowers grew from swords stuck into the ground, it would be inaccurate to relate their name with the word kardas by adding the diminutive element -elis that gives a certain connotation of warmth. Young readers would have appreciated a more popular Lithuanian word.

The fairy tale Lilija (PZ, 182-187) tells about foreign countries. It is shown both by the female name Lilija of Latin origin, as well as the name of her beloved Žaks. This French personal name has originated from the Hebrew Jakobs (Silinšs, 1990, 340, 173):

Žakam bija jādodas karā uz tālu, svešu zemi, bet vinga lïgavai Lilijai jāpaliek Francijā (PZ, 183). No šiss sirds izauga puke, ko vēl tagad sauc par liliju. Ligavu rota un kapu puke, uzticïbas, nevainibas un ceeluma simbols (PZ, 187).

"In most cases (Astra, Dälija, Lilija, Kamèlija, Roze) it is difficult to tell whether the person's name has been borrowed from other languages or it has been adopted from the name of the corresponding flower in Latvian (comp. astra, dälija, lilija, kamelija, roze); most likely, in Latvian they are borrowings" (Balodis, 2008, 28). The Latvian female name Lilija has originated from the Latin lilium "Iilija" (Siliňš, 1990, 215), whereas the name Lelija in Lithuanian is considered a Lithuanised form of the Latin word (Kuzavinis, Savukynas, 1994, 243). Thus, despite the fact that Lelija in Lithuanian has originated from Latin it is considered a native word; hence a slight discrepancy in the translation. Consequently the foreignness pervading the plot dissipates. Nevertheless, the cultural substitution in this particular translation can be justified since it corresponds to "people's ideas about symbolic meanings of flowers ( ... Lilija - innocence, faithfulness)" as found in Anna Sakse's fairy tales (Daneberga, 1990, 108).

Another tale from the cycle is connected with the phytonym analysed, even though it is not related to the source language: in the Lithuanian translation Üdensroze (PZ, 176-181) has become Vandens lelija (PG, 173-179). By transformation of the fairy tale, the translation tells about the daughter Lelija instead of Roze:

Topavasar viss pagasts posās kāzām. Un kā nu ne - staltākais un jauträkais puisis Jukums bija mainijis gredzenus ar skaistāko un krietnāko meitu Rozi (PZ, 177). Ta pavasari visa apylinke taisési i vestuves. Kurgi ne - dailiausias ir linksmiausias jaunikaitis Jukumas mainè žiedus su gražiausia ir šauniausia mergele Lelija (PG, 173). 
This kind of cultural substitution is motivated by the fact that the plant called üdensroze in Latvian (the basic component of the compound is roze), is more often referred to as lilija by Lithuanians (vandens lelija). In Latvian, too, especially in dialects, one can hear the equivalent üdenslilija. The dictionary of synonyms of the Latvian language gives the following synonyms for the word üdensrozes: lèpes, ezerrozes, ūdenslilijas along with two provincialisms - laiksnes and laiški (Grīnberga et al., 2002,433). The dictionary of Latvian plant names gives various other names or their versions, including words that contain the component lilija (Ëdelmane, Ozola, 2003, 395-397) (comp. lilija "Perennial bulbous plants in the lily family with sweet-smelling bell-shaped blossoms... Water lily - ūdensroze" (LLVV 4, 1980, 712)). In Lithuanian dialects, too, rožé and lelija are used interchangeably, however, in the literary language the phytonym vandens lelija has been accepted as a norm (on the parallels of this plant name in Lithuanian and Latvian children's poetry see also Maskuliūnienė, Kvašyte, 2010). In the end of the tale the author introduces the word ezerroze as a synonym for üdensroze (both related to water) thus accentuating the place where the plant grows:

Üdensroze, ezerroze - tā cilvēki iesauca šo puksi (PZ, 181).

In the translation the reference to the place where the plant grows with an added attribute defines the name of the flower more accurately so that it could be distinguished from other types of lilies:

Ta gèlę žmonés pavadino lelija - vandens lelija (PG, 179).

In the fairy tale Vijolite (PZ, 68-73) the depicted girl has been given a name that has allusions both with the flower vijolite ("a genus of flowering plants in the violet family Violaceae with violet, more seldom, white or various colour blossoms"), as well as with an occupation, i. e., the name of the musical instrument vijole ("the highest-pitched member of the violin family of string instruments with four strings" (LLVV 8, 1996, 473)):

Viña ieradās agrā pavasarī - maza, sīka meitenīte ar zilu vijoli padusē. Kad vina

sāka spēlēt, putni apklusa un klausijās brīniškigajās skaṇās .. (PZ, 69).

In Latvian the anthroponym Vijolite has originated from the word Vijole (Latin vijolite (a flower), but Vijole from Violeta; Latin vijole (a string instrument), whereas Violeta from Latin Viola "vijolīte" (Silin,š, 1990, 325; 329)). The translator has used the local word Kvapute for the title of the fairy tale (PG, 69-73), and the first association that comes into mind in Lithuanian is kvapas "a scent". The diminutive formed with the suffix-ute shows that it is a story about something small, young and dear, in this case, a little girl. It has to be noted, though, that the colour describing the flower appears in the masculine form, i. e., with the ending -utis; the word kvaputis has been coined from the same stem (possibly, it is a spelling mistake). Judging from the photographs in the Latvian and Lithuanian editions, the same flower is meant despite the appellatives that are not too convincing. The corresponding form of the Latvian vijolïte in Lithuanian is našlaite (Viola), and the species are: smaržìga vijolite and kvapioji našlaite (V. odorata) (LLŽ, 2003, 778). The attribute of the species 
might be the basis for the name in the Lithuanian translation: the explanation in the Lithuanian dictionary states that kvapute really is "kvapioji našlaitë" (LKŽe). The same phytonym can be found in the dictionary of Latvian plant names (Ëdelmane, Ozola, 2003, 427). It becomes clear why the translator has not chosen the phytonym našlaitè. Normally, Lithuanians know a different plant by this name - atraitnite (a pansy) (LLV, 1995, 296), however, the meaning of the Lithuanian word našlaite is also an orphan, and there is no association of the kind in the original fairy tale. Possibly, the choice of the word is related to dialect vocabulary.

In the fairy tale Naktsvijole (PZ, 112-121) we come across a familiar plot in Latvian folklore: there is a bewitched girl who can be saved only by a young man who picks the flower. In contrast to folk fairy tales where good gets the better of evil, and a girl is eventually saved from the magic power, Jānis in Anna Sakse's story has too much sympathy for the tender and fragile flower; as a result Zane who has been turned into a butterfly orchid must remain in the forest forever. The end of the tale is polysemantic. It makes the reader think about lack of self-confidence, insufficient belief in oneself that would lead away from the goal, a dream that can either be made true or ruined" (Daneberga, 1990, 104). The name of the main character Zane is not directly linked to the described phytonym; there is transformation of the story in the source and target texts.

Ap Jāniem, kad ziedēja smaržigās naktsvijoles, vinu pärṇēma dīvains nemiers

(PZ, 114).

Kad tu otrā naktī viens pats mani meklēji un biji jau tuvumā, Mežagars pārvērta mani naktsvijolē, lai paglābtu no tavām acīm. Tev vajadzēja toreiz puḳi noplūkt, tad es atkal būtu pärvērtusies Zanē (PZ, 120).

The translator has entitled the fairy tale Raganiuke (PG, 110-119) telling a story about a flower with the same name. In Latvian, naktsvijoles (butterfly orchids (Platanthera) and two of their species - lesser butterfly orchids (Platanthera bifolia or Orchis bifolus) and greater butterfly orchids (Platanthera chlorantha)) have more than 30 different names or their variations, however, only spigana (included in Latvijas flora by K. Ašmanis, published in 1923) (Ëdelmane, Ozola, 2003, 234-235) forms associations with the name of a witch. The Latvian dictionary of synonyms gives the following words as synonyms for the word naktsvijole: baltäs dzegužpukes, dzegužpieši, kreima pukses and spiganas (Grīnberga et al., 2002, 229), the latter being closest to the image of a witch. Comp. spigana "a mythological creature, a woman gleaming and deluding, seducing people; also, a witch" (LLVV, 7(2), 1991, 115). Zalziedu naktsvijole is also sometimes called zalganā spigana or kalna spigana (Ëdelmane, Ozola, 2003, 235). The Lithuanian-Latvian dictionary, on the other hand, gives the following words for naktsvijole: blandis and vakarute (LLŽ, 2003, 213), whereas the word raganiuke has not been included. Thus, a link has to be searched for with the word ragana (witch) since the title of the fairy tale in Lithuanian has the diminutive form of the respective word with the ending -(i)uke. The LithuanianLatvian dictionary does not give the word blandis, however, this phytonym can be 
found in the Directory of Lithuanian Herbs (Vilkonis, 2001, 340). One can conclude that the translator's choice is based on associations that do not correspond to the actual phytonym; the motivation lies in the plot of the fairy tale: raganiuke "a small witch".

Difference in phytonym genders. When analysing the translation of the Latvian text into Lithuanian, one must take into consideration the grammatical peculiarities of the two related languages; one of them is the difference in noun genders. Sometimes an unsuccessfully chosen word in the translation destroys the image coded in the fairy tale, in such a way ruining the story development system and logics. This has happened to the translation of the fairy tale Kirsis (PZ, 28-31) - Vyšnia (PG, 29-31). The main character of the tale is a boy who in the course of events is turned into a cherry tree. This kind of a change is provoked by the boy's naughtiness. The cherry tree named after the boy is connected with the grammatical system of the language as cherry in Latvian is a masculine noun:

Dārznieka dèlēns Kirsis patlaban sēdēja vārtu staba galà un uzmanijja tèva dārzu, kad pēkšn, ieraudzija tuvojamies l̦auno Ziemelvēju. .. "Ko darīt, kā nosargāt tēva dārzu?" domāja Kuirsis un ātrumā cita nekā nevarēja, kā pañemt akmentinu un iesviest Ziemelim bärdā (PZ, 29).

In Lithuanian the phytonym vyšnia is a feminine noun, therefore it does not suit for a boy's name. The translator chooses to tell a story about a girl, yet the perception of the fairy tale does not benefit from a transformation of the kind since there is a sound stereotype in the reader's mind: activities undertaken by the characters of the story are typical for boys. It is difficult to link the equivalent name of the character in Lithuanian with the events described in the fairy tale. Probably, it would have been more rational to use word formation potentiality. An option could have been the derivation of the diminutive noun in the masculine gender form Vyšniukas (the diminutive suffix -ukas is one of the most productive suffixes for word formation of this category in Lithuanian) (Macienè, 2002, 74); Vyšniukas would correspond to the Latvian kirsitis. One cannot miss the diversity of diminutive forms used in the translation. They prove the potential of word formation in Lithuanian: Vyšnia Vyšnele - Vyšnaité. It is interesting to note that the diminutive is not once used in the original fairy tale, even though the author might have called the tree kirsitis. At the end of the tale the name of the tree is emphasized pointing to its origin and link to the title of the fairy tale which is a characteristic feature of all tales in the cycle:

- Kirsi, mans mīlotais dèls! - tā därznieks katru pavasari uzrunā koku, un tas ar

pumpuriem piebriedušu zarinu noglauda tēva grumbainos vaigus (PZ, 31).

In the translation, the gardener respectively addresses his beloved daughter: Vyšnia, mano mylima dukrele (PG, 31).

\section{Conclusions}

After summarising observations about the fairy tale cycle Pasakas par ziediem by Anna Sakse and its translation into Lithuanian Pasakos apie gèles (translator Renata 
Zajančkauskaite), it can be concluded that the original text with the anthroponyms and their phytonyms depicts cultural environments of various countries of the world. Some of the fairy tales are addressed to children and tell about them, yet there is a considerable number of stories meant for readers of older age groups. Therefore there cannot be the same standard of the expressiveness of linguistic means. There are tales in which anthroponyms are linked with phytonyms directly: the names can be either actual personal names or personified appellatives, for instance, Lilija, Vijolite, Kirsis, Jasmins, Pienenite. In other fairy tales the link is indirect, for instance, Roze and Jukums ("Üdensroze"), Zane and Jänis ("Naktsvijole"). The translated texts present the same personal names and/or plant names as the source texts, for instance, in the fairy tale Gladioles (Gladiola in the original). Also cases of cultural substitution can be found, for instance, in the fairy tale Üdensroze the character's name is not Roze as in the original but Lilija (Vandens lelija in the translation). Occasionally the names in the translation differ from those in Latvian; this approach is justified and necessary because of the grammatical gender distinction in Latvian and Lithuanian which makes a literal translation impossible. For instance, in the fairy tale Lotoss the translator tells about princess Lota instead of Lotosas; it has to be noted though that in Latvian, too, it is a masculine noun, and therefore very unusual for the name of a princess. Another story introduces the gardener's daughter Vyšnia instead of his son as in the original tale Kirsis. There are fairy tales translated into Lithuanian not because the names of the plants correspond in both languages but because of their plot or special associations: Kvapute (fairy tale Vijolīte), Raganiuké (fairy tale Naktsvijole). In general one may conclude that the translation demonstrates a creative approach using a language appreciated by Lithuanian readers, children including.

\section{References}

1. Balodis, P. (2008). Latviešu personvārdu etimoloǵiskās semantikas teorētiskais modelis un tà realizācija [Theoretical Model of the Etymological Semantics of Latvian Personal Names and its Realization]. Synopsis of Doctoral Thesis. Riga: Latvijas Universitāte, 140 lpp. (in Latvian).

2. Bormane, Ž. (2006). Antroponimi literārā teksta tulkojumā (A. Puškina dail,rade latviešu un vācu valodā) [Anthroponyms in Fiction Translation (Creative Works by A. Pushkin in Latvian and German)]. Synopsis of Doctoral Thesis. Rīga: Latvijas Universitāte, 84 lpp. (in Latvian).

3. Daneberga, M. (1990). Latviešu literārā pasaka (Žanra attīstība prozā) [Latvian Literary Fairy-tales (the Development of the Genre in Prose)]. Doctoral Thesis. Rìga, 140 Ipp. (in Latvian).

4. DLKŽe (2006). Dabartinés lietuvių kalbos žodynas [Dictionary of Modern Lithuanian Language]. Šeštas (trečias elektroninis) leidimas. Ats. red. S. Keinys. Vilnius: Lietuvių kalbos institutes (in Lithuanian). 
5. Ėdelmane, I., Ozola, Ā. (2003). Latviešu valodas augu nosaukumi [Phytonyms in Latvian]. Rīga: Augsburgas institūts, 494 lpp. (in Latvian).

6. Ėdelmane, I., Ozola, Ā. (2007). Latviešu valodas augu nosaukumi. Pielikums. Augu nosaukumu alfabētiskais rāditājs [Phytonyms in Latvian. Supplement. Phytonyms in Alphabetical Order]. Rīga: LU Latviešu valodas institūts, 223 Ipp. (in Latvian).

7. Gaižūns, S. (2008). Latviešu literatūra Lietuvā. Latvieši, igauṇi un lietuvieši: literārie un kultūras kontakti [Latvian Literature in Lithuania]. In: [Latvians, Estonians and Lithuanians: Literary and Culture Contacts]. Rīga: LU Literatūras, folkloras un mākslas institūts, 950.-1026. Ipp. (in Latvian).

8. Grīnberga, E., Kalnciems, O., Lukstinš̌, G., Ozols, J., Pārupe, A., Rauhvargers, E. (2002). Sinonimu vārdnīca [Dictionary of Synonyms]. 3., papildinātais un pārstrādātais izdevums. Rìga: Avots, 786 Ipp. (in Latvian).

9. Gritènienè, A. (2006). Augalu pavadinimy motyvacija šiaurès panevéžiškiu patarmèje [Motivation Behind Folk Phytonyms in the Northern Panevėžys Subdialect]. Vilnius: Lietuviu kalbos institutas, 260 p. (in Lithuanian).

10. Gudavičius, A. (2009). Etnolingvistika (Tauta kalboje) [Ethnolinguistics (Nation in Language)]. Šiauliai: Všl Šiauliu universiteto leidykla, 256 p. (in Lithuanian).

11. Kanopkaitè, R. (2009). Latvių kalba lydèjo nuo lopšio [Latvian has been with me from Cradle/ A Talk with the Translator Renata Zajančkauskaite]. Šeimininke [Houskeeper], 16.10.2009. http://gyvenimas.delfi.lt/archive/article.php?id=24699681 (skatits 31.05.2010.) (in Lithuanian).

12. Karulis, K. (1992). Latviešu etimologijas värdnica [Latvian Etymology Dictionary], 2. sēj. Rīga: Avots, 671 lpp. (in Latvian).

13. Kuzavinis, K., Savukynas, B. (1994). Lietuviu vardy kilmés žodynas [Lithuanian Name Etymology Dictionary]. Vilnius: Mokslo ir enciklopediju leidykla, 391 p. (in Lithuanian).

14. Kvašìte, R. (2008). Latviešu autoru dail,darbu tulkojumi lietuviešu valodā. Latgale kā kultūras pierobeža [Translations of Latvian Literary Works in Lithuanian. In: Latgale as a Culture Borderland]. Daugavpils: Daugavpils Universitātes Akadēmiskais apgāds "Saule", 229.-245. Ipp. (in Latvian).

15. LKŽe. Lietuviu kalbos žodynas [Dictionary of Lithuanian Language]. www.Ikz.It (in Lithuanian).

16. LLV. Balkevičius, J., Balode, L., Bojāte, A., Subatnieks, V. (1995). Lietuviešu-latviešu vārdnica [Dictionary of Lithuanian-Latvian Language]. 2., pārstrādātais izdevums. Rīga: Zinātne, 656 Ipp. (in Lithuanian and Latvian).

17. LLVV. (1972-1996). Latviešu literārās valodas värdnica [Dictionary of the Latvian Literary Language]. 1.-8. sēj. Rīga: Zinātne (in Latvian).

18. LLŽ. (2003). Latviu-lietuviu kalbu žodynas [Dictionary of Latvian-Lithuanian Language]. Sud. A. Butkus. Kaunas: Aesti, 821 p. (in Latvian and Lithuanian).

19. Macienè, J. (2002). Iš lietuvių ir latviu deminutyvy tyrimo istorijos [Aspects of Research of Lithuanian and Latvian Diminutives]. In: Linguistica Lettica, Nr. 10. Rīga: LU Latviešu valodas institūts, 73.-91. Ipp. (in Lithuanian). 
20. Maskuliūnienė, Dž., Kvašytė, R. (2010). Gèlių pavadinimy semantika Janinos Degutytės ir Arturo Guobos poezijoje vaikams [Semantics of Flower Names in Poetry for Children by Janina Degutytè and Arturs Goba]. Filologija 16. Šiauliai: Všl Šiauliu universiteto leidykla, p. 99-113. (in Lithuanian).

21. PG. (2005). Sakse, A. Pasakos apie gèles [Flowers: Fairy Tales]. Vilnius: Vaga, 223 p. (in Lithuanian).

22. PZ. (b. g.) Sakse, A. Pasakas par ziediem [Flowers: Fairy Tales]. 2. izdevums. Rīga: Zvaigzne ABC, 223 lpp. (in Latvian).

23. Silinšš, K. (1990). Latviešu personvārdu värdnica [Dictionary of Latvian Personal Names]. Rīga: Zinātne, 349 Ipp. (in Latvian).

24. SV. (1999). Svešvärdu värdníca [Dictionary of Foreign Words]. Baldunčiks, J. (red.) Rīga: Jumava, 879 lpp. (in Latvian).

25. TŽŽ. (2001). Tarptautiniu žodžiu žodynas [Dictionary of Foreign Words]. Kinderys, A. (Ats. red.) Vilnius: Alma littera, 790 p. (in Lithuanian).

26. Valutytè, A. (2007). Asmenvardžiai Anos Saksès "Pasakose apie gèles" [Personal Names in Flowers: Fairy Tales by Anna Sakse]. Bachelor Paper. Šiauliai: Šiauliu universitetas, 41 p. (in Lithuanian).

27. Vilkonis, K. (2001). Lietuvos žaliasis rübas [The Green Vestiture of Lithuania]. Kaunas: Lututè, 416 p. (in Lithuanian).

28. VPSV. (2007). Valodniecïbas pamatterminu skaidrojošā värdnīca [Explanatary Dictionary of Linguistic Terms]. Sast. autoru kolektīvs V. Skujin,as vadībā. Rīga: LU Latviešu valodas institūts, 623 lpp. (in Latvian).

\section{Assoc. prof. Dr. hum. Regina Kvašytè}

Department of Lithuanian Linguistics and Communication, Šiauliai University Address: P. Višinskio g. 38, Šiauliai, LT-76352, Lietuva

Phone: +(370)-41-595785

E-mail: kvasyte@hu.su.lt 